\title{
Synthesis of 1-azabenzo[a]phenoxazin-5-one and 11-amino-1,8,10-triazabenzo[a]phenoxazin-5-one and their Functionalized Aryl Derivatives via Mizoroki-Heck Arylation Methodology
}

\section{TIMOTHY TOBA ONI, UCHECHUKWU CHRIS OKORO and DAVID IZUCHUKWU UGWU}

Department of Pure and Industrial Chemistry, University of Nigeria, Nsukka, Nigeria.
${ }^{*}$ Corresponding author: izuchukwu.ugwu@ unn.edu.ng

http://dx.doi.org/10.13005/ojc/310144

(Received: November 25, 2014; Accepted: January 10, 2015)

\begin{abstract}
The synthesis of angular 1-azabenzo[a]phenoxazin-5-one and 11-amino-1,8,10triazabenzo[a] phenoxazin-5-one and their functionalized aryl derivatives via Mizoroki-Heck arylation methodology is reported. 11-Amino-1,8,10-triazabenzo[a]phenoxazin-5-one (16) and 1azabenzo[a]phenoxazin-5-one (18) were synthesized by the reaction of 7-chloro-5,8quinolinequinone (obtained by a multistage conversion of 8-hydroxyquinoline) with 4,5-diamino-6hydroxypyrimidine and 2-aminophenol respectively in the presence of anhydrous sodium acetate. 11-Amino-1,8,10-triazabenzo[a]phenoxazin-5-one and 1-azabenzo[a]phenoxazin-5-one were subjected to Mizoroki-Heck coupling reaction by refluxing with iodobenzene derivatives, using 1,4-bis(diphenylphosphino)butane-palladium(11) chloride as catalyst, 1,4-bis-(2-hydroxy-3,5-ditertbutylbenzyl)piperazine as ligand and methanol as solvent at $60-65^{\circ} \mathrm{C}$ for $4 \mathrm{~h}$ to afford in excellent yield aryl derivatives of angular 11-amino-1,8,10-triazabenzo[a]phenoxazin-5-one (19a-c) and 1azabenzo[a]phenoxazin-5-one (20a-c) respectively. The structures were established by UV/ visible, FTIR, proton-NMR and carbon-13 NMR spectral and elemental analysis.
\end{abstract}

Key words: 1-azaphenoxazinone, 1,8,10-triazaphenoxazinobe, Mizoroki-Heck, arylation, synthesis.

\section{INTRODUCTION}

Phenoxazine derivatives are compounds of great interest because of their several successful applications as dyes and drugs. They exhibit strong biological activities ranging from antidepressant ${ }^{1}$, antitumour ${ }^{2}$, anticancer ${ }^{3}$, antibacterial ${ }^{4}$, antituberculosis ${ }^{5}$ and schizophrenia agents ${ }^{6}$.
Among the several industrial applications of phenoxazine derivatives are their use as acid-base indicator ${ }^{7}$, biological stains ${ }^{8}$, laser dyes $^{9}$ and chromophoric compounds ${ }^{10}$ in host guest artificial protonic antenna systems. Ruan et $\mathrm{a} /{ }^{11}$ has reported phenoxazinone derivatives of antitumour potential in wild-type and drug resistant tumor cells. Zaytsey et $\mathrm{al}^{12}$ reported the synthesis of chromogenic 
phenoxazinone substrate for $\beta$-alanyl amino peptidase. Abe et $a /{ }^{13}$ has reported the synthesis of 2 -amino-4, $4 \alpha$-dihydro- $4 \alpha, 7$-dimethyl- $3 \mathrm{H}$ phenoxazin-3-one that could prevent growth of human lung carcinoma cells and induce apoptosis. Gerasimova et a/ ${ }^{14}$ reported the synthesis of fluorinated benzophenoxazines via sequential $S_{N} A r$ substitution reactions of fluorinated aromatics. Jose and Burgess ${ }^{15}$ has also reported the synthesis of benzophenoxazine based fluorescent dyes used for labeling biomolecules. Carr et $a^{16}$ reported plectosphaeroic acid, a marine fungal natural product containing phenoxazine ring as inhibitor of indoleamine 2,3-dioxygenase. Amino phenoxazinone core has also been reported in numbers of bioactive substances such as exfoliazone (1), the venezuelines (2), cinnabarinic acid (3), the chandrananimycin A or B (4) to mention but a few. Jeromin ${ }^{17}$ reported phenoxazine system derivatives which have been successfully applied for phenoxyl radical stabilization. Thimmaiah et a/18 reported the synthesis of series of $\mathrm{N} 10$-substituted phenoxazines with Akt inhibitory potential. The structural modifications of parent phenoxazine ring were borne out of the need to minimize their undesirable effect and at the same time enhance the biological activities. Angular phenoxazines are phenoxazine derivatives that have non-linear arrangement of the ring system. Few examples of angular phenoxazine derivatives includes dibenzo $[a, i]$ phenoxazine (5), dibenzo[a,j] phenoxazine (6), dibenzo[a,h]phenoxazine (7) and benzopyranol [3,4-b] benzoxazine (8) in which one of the ring carbon atom was replaced with oxygen.<smiles></smiles><smiles>NC(=O)c1cccc2oc3cc(=O)c(N)c(N)c-3nc12</smiles><smiles>[R]CC(=O)Nc1cc2nc3c(C)cccc3oc-2cc1=O</smiles><smiles>c1ccc2cc3c(cc2c1)Nc1c(ccc2ccccc12)O3</smiles><smiles>c1ccc2c(c1)Nc1c(ccc3ccccc13)O2</smiles><smiles>c1ccc2c(c1)Nc1c(ccc3ccccc13)O2</smiles><smiles></smiles>

\section{EXPERIMENTAL}

Reactions were carried out under nitrogen atmosphere where necessary. Melting points were determined with a Fischer Johns melting point apparatus and are uncorrected. UV/ visible spectra were recorded in acetone on a Unicon UV- 2500PC spectrophotometer using matched $1 \mathrm{~cm}$ quartz cells, absorptions were measured in nanometer $(\mathrm{nm})$. IR spectra were recorded on 8400s Fourier Transform Infrared (FTIR) spectrophotometer and are reported in wave numbers $\left(\mathrm{cm}^{-1}\right)$. UV/visible and IR spectral analysis were done at the National Research Institute for Chemical Technology (NARICT), Zaria, Kaduna State, Nigeria. Nuclear magnetic resonance ( ${ }^{1} \mathrm{H} \mathrm{NMR}$ and ${ }^{13} \mathrm{C}$ NMR) spectra were obtained using a Jeol $400 \mathrm{MHz}$ spectrometer at Strathclyde University, Scotland. Chemical shifts are reported in $(\delta)$ scale. The elemental analysis was done on a Heraeus $\mathrm{CHN}-\mathrm{O}$ rapid analyzer. All reagents used were of technical grade and were purchased from Aldrich in sure-seal bottles and were used without further purifications.

\section{Synthesis of 8-hydroxy-5-nitrosoquinoline hydrochloride (10)}

The method of Pratt and Drake ${ }^{19}$ was used to synthesize this compound. Into a liter beaker placed in an ice bath, a solution of 8hydroxyquinoline (9) (58 g, $0.4 \mathrm{~mol})$ and water (200 $\mathrm{mL}$ ) was poured in, concentrated hydrochloric acid $(75 \mathrm{~mL})$ and ice $(200 \mathrm{~g})$ was added. Aqueous solution of sodium nitrite $\left(\mathrm{NaNO}_{2}\right)(30 \mathrm{~g})$ in water $(100 \mathrm{~mL})$ was added in portions to the mixture with vigorous stirring for over $1 \mathrm{~h}$ at $0-4{ }^{\circ} \mathrm{C}$. The mixture was allowed to stand overnight at $0^{\circ} \mathrm{C}$ and the desired product filtered and washed with cold water. The product was air dried to afford a bright yellow solid. Yield $8.2 \mathrm{~g},(92 \%), \mathrm{mp} 181{ }^{\circ} \mathrm{C}$. 


\section{Synthesis of 8-hydroxy-5-nitroquinoline (11)}

The oxidation of 8-hydroxy-5nitrosoquinoline (10) to 8-hydroxy-5-nitroquinoline (11) was carried out according to the procedure of Petrow and Sturgeon ${ }^{20}$. Finely grounded 8-hydroxy5-nitrosoquinoline hydrochloride (10) (15.0 g, 0.7 $\mathrm{mmol}$ ) was added into a $500 \mathrm{~mL}$ beaker containing concentrated nitric acid ( $45 \mathrm{~mL})$ and water $(30 \mathrm{~mL})$ in an ice bath. The mixture was stirred for $85 \mathrm{~min}$ at $17^{\circ} \mathrm{C}$. Equal volume of cold water was added and the mixture cooled to $0^{\circ} \mathrm{C}$ and alkaline was made with cold concentrated potassium hydroxide solution $\mathrm{pH}$ 13.0. The red potassium salt was decomposed on neutralization with acetic acid, filtered by suction and washed with water. The residue was recrystallized from ethanol to afford a bright yellow crystal of 8-hydroxy-5-nitroquinoline. Yield $14.10 \mathrm{~g}(90.1 \%), \mathrm{mp} 179{ }^{\circ} \mathrm{C}$ (lit 179.5-181.5 $\left.{ }^{\circ} \mathrm{C}\right)^{20}$.

\section{Synthesis of 7-chloro-8-hydroxy-5-nitroquinoline} (12)

The chlorination of 8-hydroxy-5nitroquinoline (11) was achieved using the literature $^{20}$. 8-Hydroxy-5-nitroquinoline (11) (10 g) was suspended in water $(1 \mathrm{~L})$ in a two liter beaker and potassium hydroxide $(1 \mathrm{M}, 45 \mathrm{~mL})$ was added. The mixture was stirred vigorously as sodium hypochlorite $(72 \mathrm{~mL})$ was added in portion for 90 min. After the addition of the hypochlorite, the mixture was stirred for further $2 \mathrm{~h}$, neutralized with acetic acid and stirred to ensure complete conversion of the precipitate to free quinolinol. The mixture was then filtered and washed with water and the residue recrystallized from aqueous ethyl acetate to afford 7-chloro-8-hydroxy-5-nitroquinoline as a bright orange solid. Yield $8.50 \mathrm{~g},(88 \%), \mathrm{mp} \mathrm{233-234}{ }^{\circ} \mathrm{C}$ (lit $\left.235^{\circ} \mathrm{C}\right)^{20}$. The presence of the chloro group was confirmed using sodium fusion ${ }^{21}$.

\section{Synthesis of 5-amino-7-chloro-8-hydroxy-5-} nitroquinoline (13)

The reduction of 7-chloro-8-hydroxy-5nitroquinoline (12) to 5-amino-7-chloro-8-hydroxy5-nitroquinoline (13) was achieved using the literature ${ }^{20}$. 7-Chloro-8-hydroxy-5-nitroquinoline (12) $(22.4 \mathrm{~g}, 0.1 \mathrm{mmol})$ was ground in a mortar with potassium hydroxide $(1 \mathrm{M}, 110 \mathrm{~mL})$ to ensure complete reduction of the insoluble potassium salt. The suspension was transferred with the aid of water $(280 \mathrm{~mL})$ into a litre three necked round bottom flask equipped with a long magnetic stirring bar. The mixture was heated in a water bath at 50 ${ }^{\circ} \mathrm{C}$ with vigorous stirring and potassium hydroxide (8 M, $70 \mathrm{~mL}$ ) was added while heating continued. The mixture was treated with sodium dithionate $(70$ g). The mixture was reheated; maintained at $80^{\circ} \mathrm{C}$ for 10 min while a rapid stream of nitrogen gas was passed into the flask. After $10 \mathrm{~min}$, more sodium dithionate $(10 \mathrm{~g})$ was added while the passage of nitrogen gas continued for another $10 \mathrm{~min}$. The resulting suspension was cooled in ice under nitrogen gas and the precipitate filtered off by suction, washed with cold water containing trace of dithionate and dried rapidly in an oven to give 5amino-7-chloro-8-hydroxyquinoline as a golden yellow solid. Yield $22.0 \mathrm{~g}(98 \%), \mathrm{mp} \mathrm{171-172}{ }^{\circ} \mathrm{C}$ (lit 173-174 $\left.{ }^{\circ} \mathrm{C}\right)^{20}$.

\section{7-Chloro-5,8-quinolinequinone (14)}

7-Chloro-5,8-quinolinequinone (14) was synthesized by suspending 5-amino-7-chloro-8hydroxyquinoline (13) $(22.4 \mathrm{~g}, 0.1 \mathrm{~mol})$ in water (600 $\mathrm{mL}$ ) in a litre beaker equipped with a long magnetic stirring bar in an ice-salt bath. Sulphuric acid $(6 \mathrm{M}, 18 \mathrm{~mL})$ was added to dissolve the amine, while vigorous stirring continued, the solution was cooled to $2{ }^{\circ} \mathrm{C}$ and the salt precipitated out in a finely divided form. An ice-cold solution made of potassium dichromate $(10 \%, 103 \mathrm{~mL})$ and sulphuric acid $(6 \mathrm{M}, 71 \mathrm{~mL})$ was then added. The mixture was stirred and cooled in the ice-salt bath for $15 \mathrm{~min}$. The precipitated salt was filtered in cold Buckner funnel containing trace of ice, washed with cold water and air dried to afford a light tan residue which was recrystallized from aqueous dimethyl formamide (DMF) to obtain 7-Chloro-5,8quinolinequinone as a bright yellow solid. Yield $22.2 \mathrm{~g}(99 \%), \mathrm{mp} 172-173^{\circ} \mathrm{C}$ (lit $\left.173.5-174.5^{\circ} \mathrm{C}\right)^{20}$.

\section{Synthesis of 11-amino-1,8,10-triazabenzo[a] phenoxazin-5-one (16) \\ 4,5-Diamino-6-hydroxypyrimidine (15)} (0.6 g, $0.005 \mathrm{~mol})$, sodium acetate $(1 \mathrm{~g}, 0.01 \mathrm{~mol})$ and benzene $(40 \mathrm{~mL})$ mixed with DMF $(5 \mathrm{~mL})$ were charged into a $100 \mathrm{~mL}$ three necked round bottom flask fitted with short magnetic stirring bar and a reflux condenser. The mixture was stirred while heating on a water bath at $65-75^{\circ} \mathrm{C}$ for $45 \mathrm{~min}$. 7Chloro-5,8-quinolinequinone (14) $(0.9 \mathrm{~g}, 0.005$ 
mol) was added and the stirring continued with heating at $70-75^{\circ} \mathrm{C}$ for $8 \mathrm{~h}$. The colour of the reaction mixture changed from light brown to greenish yellow, to red and intense red as the reaction progressed. After $8 \mathrm{~h}$, the reaction mixture was filtered and the solvent allowed to evaporate to afford 11-amino1,8,10-triazabenzo[a]phenoxazin-5-one (16) as intense reddish crystals. Yield $1.36 \mathrm{~g}$, (90\%), mp $287^{\circ} \mathrm{C}$. UV/vis (acetone $\left.\lambda_{\text {max }}\right)$ : $321.6(\log$ e 1.8135), 433.6 (log e 2.4450). FTIR (KBr, $\left.v, \mathrm{~cm}^{-1}\right)$ : 3420, 3289 (NH), 3090 (C-H aromatic), $1701(\mathrm{C}=\mathrm{O}), 1630,1603$, $1570(\mathrm{C}=\mathrm{N}), 1478(\mathrm{C}=\mathrm{C}), 1245(\mathrm{C}-\mathrm{O}), 1091(\mathrm{C}-\mathrm{N})$. ${ }^{1} \mathrm{H}$ NMR (DMSO-d, $\left.400 \mathrm{MHz}\right) \delta: 7.2(2 \mathrm{H}, \mathrm{d}, \mathrm{J}=8.90$ $\mathrm{Hz}, \mathrm{Ar}-\mathrm{H}), 7.0(1 \mathrm{H}, \mathrm{t}, \mathrm{J}=7.09 \mathrm{~Hz}, \mathrm{Ar}-\mathrm{H}), 6.4(1 \mathrm{H}, \mathrm{s}$, Ar-H), $6.3(1 \mathrm{H}, \mathrm{s}, 6-\mathrm{H}), 5.4\left(1 \mathrm{H}, \mathrm{s}, \mathrm{NH}_{2}\right) \cdot{ }^{13} \mathrm{C}$ NMR (DMSO-d, $400 \mathrm{MHz})$ \&: 165.40, 164.93, 162.34, 162.09, 159.90, 132.97, 132.08, 129.84, 127.29, $127.21,122.04,118.56,110.67 . \mathrm{C}_{13} \mathrm{H}_{7} \mathrm{~N}_{5} \mathrm{O}_{2}$ Calculated: C, 58.87, H, 2.66, N, 26.41, O, 12.06, found: C, 58.80, H, 2.70, N, 26.50, O, 12.02

\section{Synthesis of 1-azabenzo[a]phenoxazin-5-one (18)}

2-Aminophenol (17) (0.5 g, $0.005 \mathrm{mmol})$, sodium acetate $(1 \mathrm{~g}, 0.01 \mathrm{~mol})$ and benzene $(40 \mathrm{~mL})$ mixed with dimethyl formamide $(5 \mathrm{~mL})$ were charged into a $100 \mathrm{~mL}$ three necked round bottom flask fitted with a magnetic stirring bar and a reflux condenser. The mixture was stirred while heating on a water bath

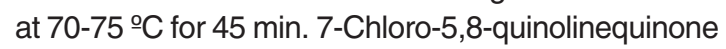
(14) $(0.9 \mathrm{~g}, 0.005 \mathrm{~mol})$ was added and the stirring continued with heating at $70-75^{\circ} \mathrm{C}$ for $8 \mathrm{~h}$. The colour of the reaction mixture changed from yellowish ash to brown, to reddish brown and intense pinkish brown as the reaction progressed. After $8 \mathrm{~h}$, the reaction mixture was filtered and the solvent evaporated from the filtrate to give 1-azabenzo[a]phenoxazin-5-one as intense brown solid. Yield $1.16 \mathrm{~g},(87 \%), \mathrm{mp} 272{ }^{\circ} \mathrm{C}$. UV/vis (acetone) $\lambda_{\text {max }}: 321.4$ (log e 1.8124), 436.8 (log e 2.4632). FTIR (KBr, $\left.v, \mathrm{~cm}^{-1}\right): 2932$ (C-H aromatic), 1586, $1583(2 \mathrm{C}=\mathrm{N}), 1488(\mathrm{C}=\mathrm{C}), 1387,1301(2 \mathrm{C}-\mathrm{O})$, 1163 (C-N), 815, 752 (substitution in benzene). ${ }^{1} \mathrm{H}$ NMR (DMSO-d, $400 \mathrm{MHz}) \delta: 7.6(\mathrm{~m}, 4 \mathrm{H}, \mathrm{Ar}-\mathrm{H}), 7.2(\mathrm{~m}$, $3 \mathrm{H}, \mathrm{Ar}-\mathrm{H}), 6.3(1 \mathrm{H}, \mathrm{s}, \mathrm{Ar}-\mathrm{H}) .{ }^{13} \mathrm{C}$ NMR (DMSO-d ${ }_{6}$, 400MHz) $\delta: 167.87,159.98,158.75,145.65,140.44$, 129.43, 128.90, 128.32, 125.76, 122.32, 121.98, 121.09, 120.08, 120.01, 117.68. $\mathrm{C}_{15} \mathrm{H}_{8} \mathrm{~N}_{2} \mathrm{O}_{2}$ calculated: C, 72.58, H, 3.25, N, 11.28, O, 12.89, found: C, 72.60, $\mathrm{H}, 3.20, \mathrm{~N}, 11.30, \mathrm{O}, 12.90$. The iodobenzene derivatives were prepared according to the method of Williamson ${ }^{22}$.
Synthesis of 11-amino-1,8,10-triazabenzo[a] phenoxazin-5-one angular derivatives (19a-c)

In a two necked round bottom flask $0.5 \mathrm{~g}$ of

1,4-bis(2-hydroxy-3,5-di-tert-butylphenyl) piperazine ligand, $0.5 \mathrm{~g}$ of 1,4 -bis(diphenyl phosphino)butane palladium(II) chloride catalyst and $5 \mathrm{~mL}$ of methanol were placed with a magnetic stirring bar. After stirring for $5 \mathrm{~min}, 11$-Amino-1,8,10triazabenzo[a]phenoxazin-5-one (16) (1.3 g, 0.005 $\mathrm{mol})$, iodobenzene derivatives $(0.005 \mathrm{~mol})$ and potassium carbonate $(0.8 \mathrm{~g})$ were added to the reaction flask. Stirring continued while heating on a water bath at $60-65{ }^{\circ} \mathrm{C}$ for $4 \mathrm{~h}$. The colour of the reaction mixture changes from pinkish red to yellowish red and intense yellow as the reaction progressed. After $4 \mathrm{~h}$, the reaction mixture was filtered and the filtrate allowed to evaporate to obtain the 11-amino-1,8,10-triazabenzo[a] phenoxazin-5-one angular derivatives in good to excellent yield.

6-(2-Carboxyphenyl)-11-amino-1,8,10triazabenzo[a]phenoxazin-5-one angular derivative (19a)

The compound was intense yellow, yield $0.7 \mathrm{~g}(56 \%), \mathrm{mp} 295^{\circ} \mathrm{C}$. UV/vis (acetone) $\mathrm{I}_{\max }: 322$ $(\log$ e 1.8158), 436 (loge 2.4587), 496.2 (log 2.7981), 546.4 (loge 3.0812). FTIR $\left(\mathrm{KBr}, v, \mathrm{~cm}^{-1}\right)$ : $3467(\mathrm{NH}), 1628(\mathrm{C}=\mathrm{O}), 1281(\mathrm{C}-\mathrm{O}) .{ }^{1} \mathrm{H}$ NMR (DMSO-d $\left.{ }_{6}, 400 \mathrm{MHz}\right) \delta: 7.8(4 \mathrm{H}, \mathrm{m}, \mathrm{Ar}-\mathrm{H}), 6.9(1 \mathrm{H}, \mathrm{s}$, Ar-H), $6.1(3 \mathrm{H}, \mathrm{m}, \mathrm{Ar}-\mathrm{H}), 5.8\left(2 \mathrm{H}, \mathrm{s}, \mathrm{NH}_{2}\right) .{ }^{13} \mathrm{C} \mathrm{NMR}$ (DMSO-d, $400 \mathrm{MHz}) \delta: 171.09,167.05,162.89$, $162.01,160.32,159.80,142.01,140.90,140.34$, $132.21,132.10,130.98,130.05,130.01,128.92$, 128.41, 125.55, 124.59, 124.07, 121.95. $\mathrm{C}_{20} \mathrm{H}_{11} \mathrm{~N}_{5} \mathrm{O}_{4}$ calculated: C, 62.34, H, 2.88, N, 18.17, O, 16.61, found: C, 62.30, H, 2.90, N, 18.16, O, 16.61

6 - ( 4 - nitrophe ny ) - 11 - a m in o-1, 8, 10 triazabenzo[a]phenoxazin-5-one angular derivative (19b)

The compound was brownish in colour, yield $1.0 \mathrm{~g}(87 \%), \mathrm{mp} 301^{\circ} \mathrm{C}$. UV/vis (acetone) $\lambda_{\max }$ : 326.6 (loge 1.8417), 360 (loge 2.0301), 397.4 (loge 2.2410), 497 (loge 2.8027), 654.6 (loge 3.6914). FTIR (KBr, $\left.v, \mathrm{~cm}^{-1}\right): 3366,3258(2 \mathrm{NH}), 3092(\mathrm{C}-\mathrm{H}$ aromatic), $1710(\mathrm{C}=\mathrm{O}), 1589(\mathrm{C}=\mathrm{N}), 1494(\mathrm{C}=\mathrm{C})$, 1291 (C-O), 1169, 1094 (C-N), 841, 750 (substitution in benzene). ${ }^{1} \mathrm{H}$ NMR (DMSO- $\left.\mathrm{d}_{6}, 400 \mathrm{MHz}\right) \delta: 7.2$ $(2 \mathrm{H}, \mathrm{d}, \mathrm{J}=8.23 \mathrm{~Hz}, \mathrm{Ar}-\mathrm{H}), 7.0(2 \mathrm{H}, \mathrm{d}, \mathrm{J}=7.89 \mathrm{~Hz}, \mathrm{Ar}-$ 
$\mathrm{H}), 6.7(3 \mathrm{H}, \mathrm{m}, \mathrm{Ar}-\mathrm{H}), 6.2(1 \mathrm{H}, \mathrm{s}, \mathrm{Ar}-\mathrm{H}) .{ }^{13} \mathrm{C}$ NMR (DMSO-d, $400 \mathrm{MHz}) \delta: 165.98,162.09,161.78$, $160.60,159.89,159.09,150.76,150.53,138.85$, 135.32, 133.22, 133.01, 131.33, 130.92, 128.57, 127.06, 123.09, 120.70, 118.02. $\mathrm{C}_{19} \mathrm{H}_{10} \mathrm{~N}_{6} \mathrm{O}_{4}$ calculated: C, 59.07, H, 2.61, N, 21.75, O, 16.57, found: C, 59.00, H, 2.60, N, 21.80, O, 16.60.

6 - (4-hydroxyphenyl)-11-amino-1,8,10triazabenzo[a]phenoxazin-5-one angular derivative (19c)

The compound was coloured ash, yield $0.7 \mathrm{~g}(78 \%), \mathrm{mp} 320^{\circ} \mathrm{C}$. UV/vis (acetone) $\lambda_{\max }: 326.6$ (loge 1.8417), 440.6 (loge 2.4846), 503.2 (loge 2.8376), 654.6 (loge 3.6914). FTIR ( $\left.\mathrm{KBr}, \mathrm{v}, \mathrm{cm}^{-1}\right)$ : 3584, 3299 (2NH), 2941 (C-H aromatic), 1690 $(\mathrm{C}=\mathrm{O}), 1589(\mathrm{C}=\mathrm{N}), 1483(\mathrm{C}=\mathrm{C}), 1303(\mathrm{C}-\mathrm{O}), 1125$ (C-N), 817, 759 (substitution in benzene). ${ }^{1} \mathrm{H}$ NMR (DMSO- $\left.\mathrm{d}_{6}, 400 \mathrm{MHz}\right) \delta: 7.1(4 \mathrm{H}, \mathrm{m}, \mathrm{Ar}-\mathrm{H}), 6.6(3 \mathrm{H}$, m, Ar-H), $6.3(2 \mathrm{H}, \mathrm{d}, \mathrm{J}=7.82 \mathrm{~Hz}, \operatorname{Ar}-\mathrm{H}), 6.1(2 \mathrm{H}, \mathrm{d}, \mathrm{J}=$ $8.23 \mathrm{~Hz}, \mathrm{Ar}-\mathrm{H}) \cdot{ }^{13} \mathrm{C}$ NMR (DMSO-d, $400 \mathrm{MHz}$ ) $\delta: 162.21,160.08,159.90,154.34,150.97,137.60$, $137.21,132.45,132.12,129.87,129.09,126.32$, 126.08, 122.96, 122.23, 120.09, 117.07, 115.76, 115.02. $\mathrm{C}_{19} \mathrm{H}_{11} \mathrm{~N}_{5} \mathrm{O}_{3}$ calculated: $\mathrm{C}, 63.86, \mathrm{H}, 3.10$, $\mathrm{N}, 19.60, \mathrm{O}, 13.43$, found: C, 63.90, H, 3.00, N, $19.58,0,13.40$

\section{Synthesis of 1-azabenzo[a]phenoxazin-5-one angular derivatives (20a-c)}

Into a two necked round bottom flask equipped with magnetic stirring bar, the mixture of 1,4-bis(2-hydroxy-3,5-di-tert-butylbenzyl) piperazine ligand $(0.5 \mathrm{~g}), \quad 1,4$-bis (diphenylphosphino)butane palladium(II) chloride catalyst $(0.5 \mathrm{~g})$ and methanol $(5 \mathrm{~mL})$ were placed. After stirring for $5 \mathrm{~min}, 1$-azabenzo[a] phenoxazin5-one (18) (1.2 g, $0.005 \mathrm{~mol})$, iodobenzene derivatives $(0.005 \mathrm{~mol})$ and potassium carbonate $(0.8 \mathrm{~g})$ were added to the reaction mixture, stirring continued while heating on a water bath at 60-65 ${ }^{\circ} \mathrm{C}$ for $4 \mathrm{~h}$, the colour of the reaction mixture changes from pinkish red to yellowish red and intense yellow as the reaction progressed. After $4 \mathrm{~h}$, the reaction mixture was filtered and the filtrate was allowed to evaporate to dryness before extracting the product with acetone. The acetone extract was allowed to evaporate to obtain 1-azabenzo[a]phenoxazin-5one angular derivatives in excellent yield.

\section{6-(2-carboxyphenyl)-1-azabenzo[a]phenoxazin-} 5-one angular derivative (20a)

The compound was yellow in colour, yield $0.9 \mathrm{~g}(87 \%), \mathrm{mp} 307^{\circ} \mathrm{C}$. UV/vis (acetone) $\lambda_{\max }: 321.2$ (loge 1.8113), 360 (loge 2.4722), 438.4 (loge 2.8162), 544.2 (loge 3.0688), 656 (loge 3.7004). FTIR (KBr, v, cm-1): 3473 (broad, OH), 2980 (C-H aromatic), $1576(\mathrm{C}=\mathrm{N}), 1480(\mathrm{C}=\mathrm{C}), 1288(\mathrm{C}-\mathrm{O})$, 1127 (C-N), 746 (substitution in benzene). ${ }^{1} \mathrm{H}$ NMR (DMSO-d, $400 \mathrm{MHz}) \delta: 7.3(\mathrm{~m}, 4 \mathrm{H}, \mathrm{Ar}-\mathrm{H}), 6.8(3 \mathrm{H}$, $\mathrm{m}, \mathrm{Ar}-\mathrm{H}), 6.1(4 \mathrm{H}, \mathrm{m}, \mathrm{Ar}-\mathrm{H}) \cdot{ }^{13} \mathrm{C}$ NMR (DMSO- $\mathrm{d}_{6}$, $400 \mathrm{MHz}) \delta: 171.00,162.89,155.80,150.85,145.01$, $142.00,140.84,130.20,128.41,128.01,126.67$, $125.85,125.59,124.70,123.95,123.56,123.05$, $120.89,120.45,119.03,117.65,115.54$. $\mathrm{C}_{22} \mathrm{H}_{12} \mathrm{~N}_{2} \mathrm{O}_{4}$ calculated: $\mathrm{C}, 71.74, \mathrm{H}, 3.28, \mathrm{~N}, 7.61$, O, 17.37, found: C, 71.80, H, 3.30, N, 7.60, O, 17.30.

\section{6-(4-nitrophenyl)-1-azabenzo[a]phenoxazin-5-} one angular derivative (20b)

The compound was intense yellowish in colour, yield $1.1 \mathrm{~g},(98 \%), \mathrm{mp} 300{ }^{\circ} \mathrm{C}$. UV/vis (acetone) $\lambda_{\max }: 321.6$ (loge 1.8135), 360 (loge 2.2151), 392.8 (loge 2.8117), 498.6 (log 3.0812), 655.4 (loge 3.6959). FTIR (KBr, $\left.v, \mathrm{~cm}^{-1}\right)$ : $3100(\mathrm{C}-\mathrm{H}$ aromatic), 1627 (C=O), 1282 (C-O). ${ }^{1} \mathrm{H}$ NMR (DMSO-d, $400 \mathrm{MHz}) \delta: 7.9(2 \mathrm{H}, \mathrm{d}, \mathrm{J}=9.04 \mathrm{~Hz}$, Ar$\mathrm{H}), 7.0(2 \mathrm{H}, \mathrm{d}, \mathrm{J}=6.89 \mathrm{~Hz}, \mathrm{Ar}-\mathrm{H}), 6.5(3 \mathrm{H}, \mathrm{m}, \mathrm{Ar}-\mathrm{H})$, $6.1(4 \mathrm{H}, \mathrm{m}, \mathrm{Ar}-\mathrm{H}) .{ }^{13} \mathrm{C}$ NMR (DMSO- $\left.\mathrm{d}_{6}, 400 \mathrm{MHz}\right) \delta$ : $169.11,167.25,160.22,159.88,132.23,132.01$, $130.88,130.15,130.06,128.99,128.11,125.45$, $124.99,124.17,121.55,120.89,120.04,118.98$, 116.27, 115.70, 110.01. $\mathrm{C}_{21} \mathrm{H}_{11} \mathrm{~N}_{3} \mathrm{O}_{4}$ calculated: $\mathrm{C}$, $68.29, \mathrm{H}, 3.00, \mathrm{~N}, 11.38, \mathrm{O}, 17.33$, found: C, 68.30, $\mathrm{H}, 3.00, \mathrm{~N}, 11.36, \mathrm{O}, 17.32$

\section{6-(4-hydroxyphenyl)-1-azabenzo[a]phenoxazin- 5-one angular derivative (20c)}

The compound was ash in colour, yield $0.8 \mathrm{~g}(87 \%), \mathrm{mp} 330^{\circ} \mathrm{C}$. UV/vis (acetone) $\lambda_{\max }: 321.8$ (loge 1.8147), 437.6 (loge 2.4677), 498.4 (loge 2.8105). FTIR (KBr, $\left.v, \mathrm{~cm}^{-1}\right)$ : 3436 (broad, OH), 2935 (C-H aromatic), $1581(\mathrm{C}=\mathrm{N}), 1486(\mathrm{C}=\mathrm{C}), 1288$ (CO), 1164 (C-N), 838, 758 (substitution in benzene). ${ }^{1} \mathrm{H}$ NMR (DMSO-d, $\left.400 \mathrm{MHz}\right) \delta: 6.9(2 \mathrm{H}, \mathrm{d}, \mathrm{J}=8.74$ $\mathrm{Hz}, \mathrm{Ar}-\mathrm{H}), 6.6(2 \mathrm{H}, \mathrm{d}, \mathrm{J}=7.88 \mathrm{~Hz}, \mathrm{Ar}-\mathrm{H}), 6.5(2 \mathrm{H}, \mathrm{d}$, $J=8.93 \mathrm{~Hz}, \mathrm{Ar}-\mathrm{H}), 6.3(1 \mathrm{H}, \mathrm{t}, \mathrm{J}=8.04 \mathrm{~Hz}, \mathrm{Ar}-\mathrm{H}), 6.1$ $(4 \mathrm{H}, \mathrm{m}, \mathrm{Ar}-\mathrm{H}) .{ }^{13} \mathrm{C}$ NMR (DMSO-d, $\left.400 \mathrm{MHz}\right) \delta$ : $165.55,159.22,158.28,132.32,132.11,130.88$, $130.15,128.90,128.14,125.44,124.49,124.18$, 
$121.65,120.88,120.14,118.78,116.36,115.08$, 112.98, 112.09, 110.02. $\mathrm{C}_{21} \mathrm{H}_{12} \mathrm{~N}_{2} \mathrm{O}_{3}$ calculated: $\mathrm{C}$, 74.11, H, 3.55, N, 8.23, O, 14.10, found: C, 74.10, H, $3.52, \mathrm{~N}, 8.20, \mathrm{O}, 14.15$

\section{RESULT AND DISCUSSION}

The synthesis of 1-azabenzo[a] phenoxazin-5-one (18) was achieved by the reaction of 2-aminophenol (17) and 7-chloro-5,8quinolinequinone (14) in the presence of sodium acetate at $70-75^{\circ} \mathrm{C}$ for $8 \mathrm{~h}$ (scheme 2). The reaction of 1-azabenzo[a]phenoxazin-5-one (18) with iodobenzene derivatives in the presence of 1,4bis(2-hydroxy-3,5-di-tert-butylbenzyl)piperazine as ligand, 1,4-bis(diphenylphosphino)butane palladium(II) chloride as catalyst, methanol as solvent and triethylamine as base at $60-65^{\circ} \mathrm{C}$ under reflux for $4 \mathrm{~h}$ gave the aryl derivatives of angular 1 azabenzo[a]phenoxazin-5-one (20a-c) in excellent yield (scheme 4). 11-Amino-1,8,10-triazabenzo[a] phenoxazin-5-one (16) was synthesized by the reaction of 4,5-diamino-6-hydroxypyrimidine (15) and 7-chloro-5,8-quinolinequinone (14) in the presence of sodium acetate at $70-75^{\circ} \mathrm{C}$ for $8 \mathrm{~h}$ using benzene/dimethyl formamide as solvent (scheme 2). The reaction of 11-amino-1,8,10-triazabenzo [a]phenoxazin-5-one (16) with iodobenzene derivatives in the presence of 1,4-bis(2-hydroxy3,5-di-tert-butylbenzyl)piperazine as ligand, 1,4bis(diphenylphosphino)butane palladium(II) chloride as catalyst, methanol as solvent and triethylamine as base at $60-65^{\circ} \mathrm{C}$ under reflux for 4 $\mathrm{h}$ gave the aryl derivatives of angular 11-amino1,8,10-triazabenzo[a]phenoxazin-5-one (19a-c) in excellent yield (scheme 3 ). The iodobenzene derivatives and 7-chloro-5,8-quinolinequinone (scheme 1) were prepared according to the literature and their purity ascertained using melting point. The synthesized monoaza and triazabenzo[a]phenoxazin-5-ones and their functionalized derivatives were characterized using UV/visible, FTIR, ${ }^{1} \mathrm{H}$ NMR and ${ }^{13} \mathrm{C}$ NMR spectroscopies and elemental analysis. The proposed structures of the novel compounds were in agreement with spectral and elemental analysis.

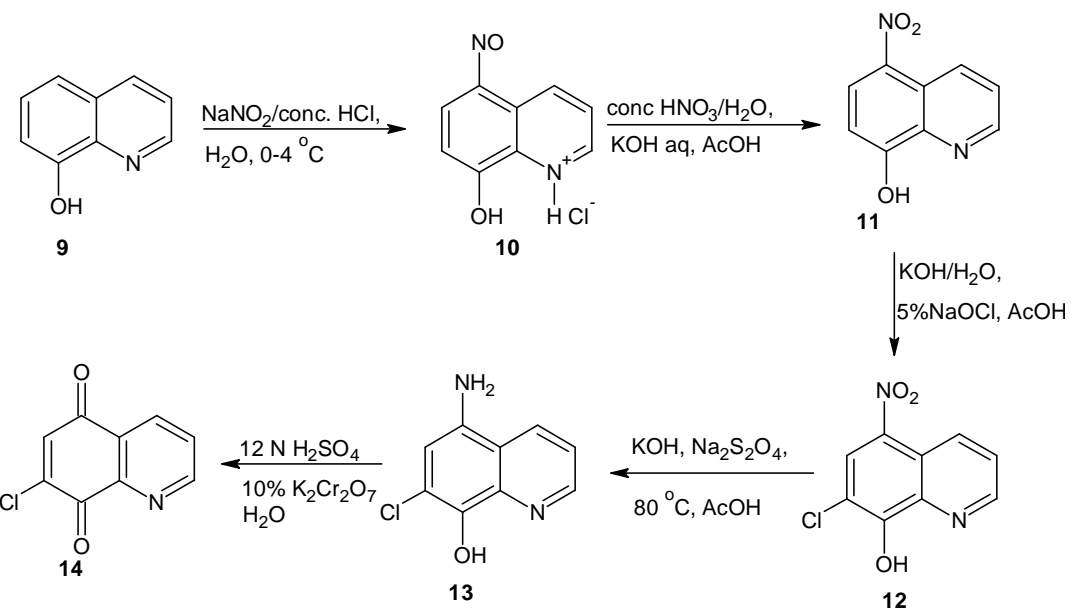

Scheme 1:<smiles></smiles><smiles>O=C1C=C(Cl)C(=O)c2ncccc21</smiles><smiles>Nc1ncnc(O)c1N</smiles>
15 $\underset{\mathrm{NaAc}, \mathrm{C}_{6} \mathrm{H}_{6} / \mathrm{DMF}}{\longrightarrow}$ $65-75^{\circ} \mathrm{C}, 8 \mathrm{~h}$<smiles>Nc1ncnc2oc3cc(=O)c4cccnc4c-3nc12</smiles>

16

Scheme 2: 

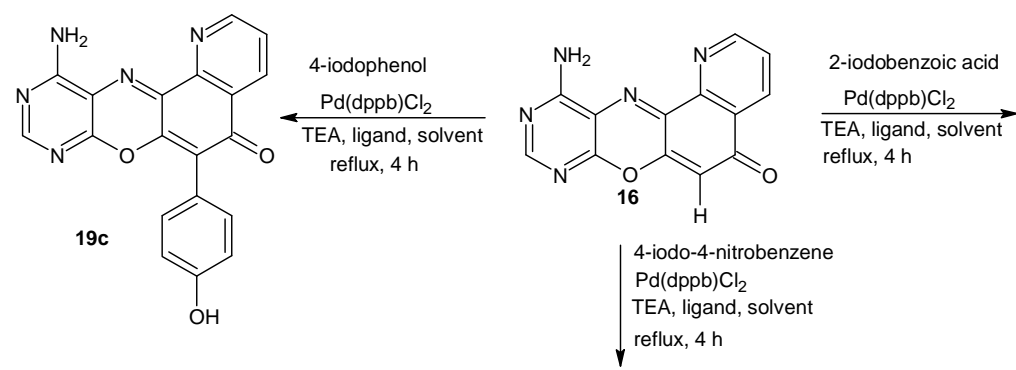<smiles>Nc1ncnc2oc3c(-c4ccccc4C(=O)O)c(=O)c4cccnc4c-3nc12</smiles><smiles>Nc1ncnc2oc3c(-c4ccc([N+](=O)[O-])cc4)c(=O)c4cccnc4c-3nc12</smiles>

Scheme 3:
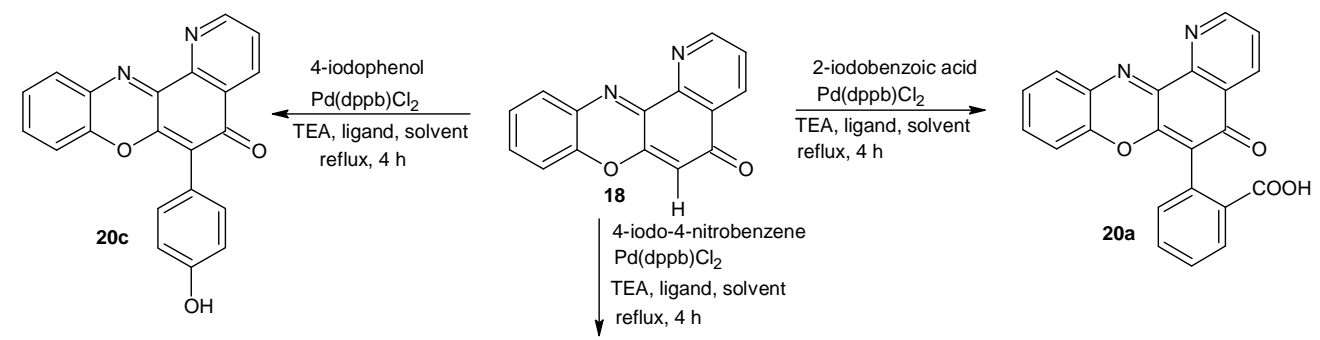<smiles>O=c1c(-c2ccc([N+](=O)[O-])cc2)c2oc3ccccc3nc-2c2ncccc12</smiles>

Scheme 4:

\section{REFERENCES}

1. Samet, A. V.; Kislyi, K. A.; Marshalkin, V. N.; Semenov, V. V. Izv. Ross. Akad. Nauk, Ser. Khim. 2006, 529

2. Shimamoto, T.; Tomoda, A.; Ishida, R.; Ohyashiki, K. Am. Assoc. Can. Res. 2001, 7 , 704-708.

3. Horton, J. K.; Thimmaiah, K. N.; Harwood, F. C.; Kuttesch, J. F.; Houghton, P. J. Mol.
Pharmacol. Abstract, 1993, 44, 552-559.

4. Chu-Daniel, T. U. S. Chem. Abstr. 1986, 104, 109663K.

5. Boothroyd, B.; Clark, E. R. J. Chem. Soc. 1952, 1499.

6. Kapur, S.; McClelland, R. US patent 6890919 , 2005.

7. Mass, H.; Khatyr, A.; Calzaferri, G. 
Microporous and Mesoporous Material, 2003, 65, 233-242.

8. Eregowda, G. B.; Kalpana, H. N.; Hegbe, R.; Thimmiah, K. N. Ind. J. Chem. Soc.2000, 39B, 24.

9. Okafor, C. O. Phosphorus and Sulphur, 1978, 4, 79.

10. Newman, M.S.; Perry, C.Y. J. Org. Chem. 1963, 28, 116.

11. Ruan, J. W.; Huang, Z. S.; Huang, J. F.; Du, C. J.; Huang, S. L.; Shi, Z.; Fu, L. W.; Gu, L. Q. Chinese Chemical Letters, 2006, 17(9), 06.

12. Zaytsey, A. V.; Anderson, R. J.; Bedernjack, A.; Groundwater, P. W.; Huang, Y.; Perry, J. D.; Orenga, S.; Roger-Dalbert, C.; James, A. Org. Biomol. Chem., 2008, 6, 682-692.

13. Abe, A.; Yamane, M.; Tomoda, A. Anticancer Drugs 2001, 12 (4), 377-382.

14. Gerasimova, T. N.; Kolchina, E. F.; Kargapolova, I. Y.; Fokin, E. P. Russ. J. Org. Chem. 1997, 33, 735-739.

15. Jose, J.; Burgess, K. Tetrahedron, 2006, 62, 11021-11037.
16. Carr, G.; Tay, W.; Bottriell, H.; Andersen, S. K.; Mauk, A. G.; Andersen, R. J. Org. Lett. 2009, 11, 2996-2999.

17. Jeromin, G. E. Tetrahedron Lett. 2001, 42, 1863-1865.

18. Thimmaiah, K. N.; Easton, J. B.; Germain, G. S.; Morton, C. L.; Kamath, S.; Buolamwini, J. K..; Houghton, P. J. J. Biol. Chem., 2005, 280(36), 31924-31935.

19. Pratt, Y.T.; Drake, N. L. JACS, 1960, 82, 11521160.

20. Petrov, V.; Sturgeon, B. J. Chem. Soc., 1954, 570-574.

21. Furniss, B. S.; Hannaford, A. J.; Rogers, V.; Smith, P. W. G.; Tatchell, A. R. Vogel's Textbook of Organic Chemistry $4^{\text {th }}$ ed. Longman, England 934-936, 1978.

22. Williamson, K. L. Macroscale and Microscale Organic Experiments $3^{\text {rd }}$ ed. Houghton, US, 518, 1999.

23. Brian, S. F.; Antony, J. H.; Peter, W. G.; Austin, R. T. Vogel's Textbook of Organic Chemistry $4^{\text {th }}$ ed. Longman, England, 930-933, 1989. 